\title{
Innovative Insulating Materials from Coriander (Coriandrum sativum L.) Straw for Building Applications
}

\author{
Evelien Uitterhaegen
}

Université de Toulouse, Toulouse INP, INRAE, Laboratoire de Chimie Agro-industrielle, ENSIACET, 4 Allée Emile Monso, BP 44362, 31030 Toulouse Cedex 4, France

Tel: + 33 (0)534323500Ｅ-mail: evelien.uitterhaegen@ outlook.com

\section{Laurent Labonne}

Université de Toulouse, Toulouse INP, INRAE, Laboratoire de Chimie Agro-industrielle, ENSIACET, 4 Allée Emile Monso, BP 44362, 31030 Toulouse Cedex 4, France

Tel: + 33 (0)5 $34323500 \quad$ E-mail: Laurent.Labonne@ensiacet.fr

Othmane Merah

Université de Toulouse, Toulouse INP, INRAE, Laboratoire de Chimie Agro-industrielle, ENSIACET, 4 Allée Emile Monso, BP 44362, 31030 Toulouse Cedex 4, France

Tel: + 33 (0)5 $34323500 \quad$ E-mail: Othmane.Merah@ensiacet.fr

Thierry Talou

Université de Toulouse, Toulouse INP, INRAE, Laboratoire de Chimie Agro-industrielle, ENSIACET, 4 Allée Emile Monso, BP 44362, 31030 Toulouse Cedex 4, France

$$
\text { Tel: + } 33 \text { (0)5 } 34323500 \quad \text { E-mail: Thierry.Talou@ensiacet.fr }
$$

Stéphane Ballas

Ovalie Innovation, 2 Rue Marguerite Duras, ZAC du Mouliot, 32000 Auch, France

Tel: + 33 (0)5 $62604020 \quad$ E-mail: stephane.ballas@ ovalie-innovation.com

Thierry Véronèse 
Ovalie Innovation, 2 Rue Marguerite Duras, ZAC du Mouliot, 32000 Auch, France

Tel: + 33 (0)562604020Ｅ-mail: thierry.veronese@ ovalie-innovation.com

\author{
Philippe Evon (Corresponding author) \\ Université de Toulouse, Toulouse INP, INRAE, Laboratoire de Chimie Agro-industrielle, \\ ENSIACET, 4 Allée Emile Monso, BP 44362, 31030 Toulouse Cedex 4, France \\ Tel: + 33 (0)5 $34323500 \quad$ E-mail: Philippe.Evon@ensiacet.fr
}

Received: May 22, 2020

doi:10.5296/jas.v8i4.17077
Accepted: June 22, 2020 Published: June 29, 2020

URL: https://doi.org/10.5296/jas.v8i4.17077

\begin{abstract}
Straw represents $60-80 \%$ of the aerial part of the coriander plant. Because of the increasing demand for vegetable oil from fruits for food, cosmetics or the chemical industry, the availability of straw will grow strongly in the future. Its high lignocellulose content $(62 \%)$ makes this crop by-product an interesting raw material for producing bio-based building materials. Bulk materials can be obtained by refining the straw through twin-screw extrusion in the presence of water. The fiber aspect ratio of refined straw can be varied (22.9-26.5) by applying different liquid/solid ratios (0.4-1.0), leading to a variation in the tapped density of the resulting bulk material $\left(110-61 \mathrm{~kg} / \mathrm{m}^{3}\right)$. For the lowest density, thermal conductivity is $47.3 \mathrm{~mW} /(\mathrm{m} . \mathrm{K})$. Twin-screw refining can also be conducted from an aqueous borax solution. Refined straw thus becomes fire-proofed, making it usable as loose fill in housing. Insulation blocks of medium density, associating straw and a starch-based binder, can also be produced through compression molding. With a density of $155 \mathrm{~kg} / \mathrm{m}^{3}$ and a thermal conductivity of $55.6 \mathrm{~mW} /(\mathrm{m} . \mathrm{K})$, the optimal cohesive blocks $(7.5 \mathrm{~mm}$ milled straw and $15 \%$ binder $)$, cold-pressed at $87 \mathrm{kPa}$ for $30 \mathrm{~s}$, are promising alternatives for the thermal insulation of buildings (e.g., filling of walls, interior partitions, etc.).
\end{abstract}

Keywords: coriander, straw, lignocellulose, twin-screw extrusion refining, compression molding, building insulation materials

\title{
1. Introduction
}

Largely used as a condiment or a spice, coriander (Coriandrum sativum L.) is an annual herb. Its fruit has already proved its interest in traditional medicine, for treating indigestion, worms, rheumatism, joint pain, etc. In addition, a twin-screw extruder can be used for the mechanical extraction of the vegetable oil from fruit (Uitterhaegen et al., 2015). The pressed oils obtained reveal interesting characteristics: an acidity of less than $1.5 \%$, a negligible peroxide value, and a high petroselinic acid content (73\%). During mechanical pressing, the coriander 
essential oil is also partly extracted from fruits, leading to the production of a pleasantly scented vegetable oil.

Although straw is the crop residue of the coriander plant, its proportion by weight represents up to $80 \%$ of the aerial part of coriander. It is cheap, with an estimated price of around 90 $€ /$ ton (price including harvesting, bunching, and also transportation). In the southwestern part of France, 250 tons of coriander straw is currently available per year. However, because vegetable oil from fruits is of great interest for the food, cosmetic and chemical industries, an increase in the availability of straw is expected for the coming years (Uitterhaegen et al., 2016). Because of its high lignocellulosic fiber content (Uitterhaegen et al., 2017, 2018), one possible future application for coriander straw could be found in the manufacture of insulating materials for buildings.

The following section therefore reviews the state of the art of, on the one hand, the already known uses of coriander straw for applications in materials and, on the other, the manufacture of thermal insulation materials for buildings from various plant fibers other than coriander straw.

\section{Literature Review}

\subsection{Known Applications of Coriander Straw in the Field of Materials}

A recent study from Uitterhaegen et al. (2018) showed that coriander straw had the ability to mechanically reinforce polypropylene (PP) and bio-based low-density polyethylene (BioPE) when used as a filler. The process developed in that study involved two successive steps: compounding through twin-screw extrusion to produce homogeneous granules and then injection molding to obtain the composite material. Compared to the native polymers, the composites showed an increase in flexural and tensile strengths of up to $50 \%$ - from $19 \mathrm{MPa}$ to $28 \mathrm{MPa}$ for PP and from $12 \mathrm{MPa}$ to $17 \mathrm{MPa}$ for BioPE. Those results are proof of a real reinforcing ability of coriander straw, comparable to those of two commercial wood fibers tested in the same study, softwood and hardwood flours. The $40 \%$ filled thermoplastic biocomposites also revealed an excellent durability after aging by UV and hygrothermal weathering, and a real ability for recycling.

Renewable binderless fiberboards can also be manufactured from coriander straw through hot pressing, where fibers from the straw provide mechanical reinforcement. Uitterhaegen et al. (2016) obtained cohesion of the board by adding the cake originating from the mechanical pressing of vegetable oil from fruits to the straw. In fact, this protein-based process by-product acted as a natural binder in fiberboards. With $29 \mathrm{MPa}$ flexural strength and $24 \%$ thickness swelling, the optimal board in that study had promising characteristics. Produced without adding any chemical adhesive, it revealed negligible formaldehyde emission $(<0.2$

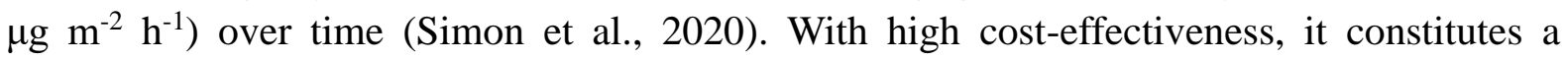
sustainable and viable alternative for commercial materials from wood, e.g., oriented strand board, particleboard, and medium-density fiberboard.

\subsection{Thermal Insulation of Buildings Using Renewable Fibers Other Than Coriander Straw}

The heat insulation of buildings (walls, ceilings, etc.) can be another use for fiberboards 
originating from crop residues. Here, fibers of renewable origin have many advantages. They are abundant and cheap, they have a reduced impact on the environment, and they are also independent of fossil resources. Lastly, vegetable fibers have interesting natural heat insulation properties (Saiah et al., 2010). Many different agricultural by-products have been used in the last twenty years to obtain innovative insulating boards. The renewable fibers used can originate from a mixture of durian peels and coconut coir (Khedari et al., 2003), kenaf (Ardente et al., 2008), flax and hemp (Kymäläinen \& Sjöberg, 2008; Korjenic et al., 2011; Benfratello et al., 2013), cotton stalk (Zhou et al., 2010), jute (Korjenic et al., 2011), coconut (Panyakaew \& Fotios, 2011; Alavez-Ramirez et al., 2012), pith from sunflower stalk (Vandenbossche et al., 2012; Sabathier et al., 2017), cake from the whole plant of sunflower (Evon et al., 2014, 2015), date palm (Chikhi et al., 2013), etc.

The density of the insulation boards often influences their thermal conductivity (Khedari et al., 2003; Zhou et al., 2010; Panyakaew \& Fotios, 2011; Vandenbossche et al., 2012; Benfratello et al., 2013; Chikhi et al., 2013; Evon et al., 2014, 2015). The best insulating materials are those with the lowest density values, which result in reduced thermal conductivities. For example, a $38 \mathrm{~mW} /(\mathrm{m} . \mathrm{K})$ thermal conductivity at $25{ }^{\circ} \mathrm{C}$ was obtained from an insulation board made of sunflower pith and thus having a particularly low density, of $36 \mathrm{~kg} / \mathrm{m}^{3}$ (Vandenbossche et al., 2012). This thermal conductivity value was in the same range as those of conventional thermal insulating materials, such as expanded polystyrene, rock wool, and glass wool: $37 \mathrm{~mW} /(\mathrm{m} . \mathrm{K}), 36 \mathrm{~mW} /(\mathrm{m} . \mathrm{K})$, and $35 \mathrm{~mW} /(\mathrm{m} . \mathrm{K})$, respectively, with board densities of $50 \mathrm{~kg} / \mathrm{m}^{3}, 115 \mathrm{~kg} / \mathrm{m}^{3}$, and $26 \mathrm{~kg} / \mathrm{m}^{3}$, respectively.

In the case of insulation materials with medium density, the thermal conductivity is higher: 46-68 $\mathrm{mW} /(\mathrm{m} . \mathrm{K})$ for boards from coconut husks having densities of $250-350 \mathrm{~kg} / \mathrm{m}^{3}$ (Panyakaew \& Fotios, 2011), 74-83 mW/(m.K) for boards from sunflower cake having densities of 338-375 kg/m 3 (Evon et al., 2015), $82 \mathrm{~mW} /(\mathrm{m} . \mathrm{K})$ for a board from cotton stalk fibers having a density of $450 \mathrm{~kg} / \mathrm{m}^{3}$ (Zhou et al., 2010), $90-108 \mathrm{~mW} /(\mathrm{m} . \mathrm{K}$ ) for boards from hemp fibers having densities of $369-475 \mathrm{~kg} / \mathrm{m}^{3}$ (Benfratello et al., 2013), $104 \mathrm{~mW} /(\mathrm{m} . \mathrm{K}$ ) for a board from coconut coir having a density of $540 \mathrm{~kg} / \mathrm{m}^{3}$ (Khedari et al., 2003), and 150 $\mathrm{mW} /\left(\mathrm{m} . \mathrm{K}\right.$ ) for a board from date palm fibers having a density of $754 \mathrm{~kg} / \mathrm{m}^{3}$ (Chikhi et al., 2013). Despite their higher thermal conductivity values, such boards are nonetheless viable options for the thermal insulation of buildings, e.g., when used in walls and ceilings.

To significantly improve the thermal properties of insulation fiberboards, one strategy can be to use natural binders (Mati-Baouche et al., 2014; Evon et al., 2015). Such binders are solubilized in water before being mixed with the crop residue for compression molding and then drying. They are external binders with physical curing, meaning that the adhesion is achieved at the same time as water evaporates at the moment of the drying step. Hydrogen bonds are then formed between the biopolymer in the glue and the lignocellulosic chemicals inside the crop residue, primarily cellulose and hemicelluloses. In fact, natural binders bring both strong cohesion and low density to the final material, and its thermal insulation ability can thus be improved. For example, bio-based insulating composites were manufactured using this technique with particles from sunflower stalk as the crop residue and chitosan as the natural binder (Mati-Baouche et al., 2014). From a 4.3\% (w/w) ratio of chitosan and 
sunflower stalk particles larger than $3 \mathrm{~mm}$, the thermal conductivity of the resulting composite was only $56 \mathrm{~mW} /(\mathrm{m} . \mathrm{K})$, and its maximum stress was $2 \mathrm{MPa}$. Thermal insulation fiberboards were also successfully manufactured with this technique using the cake generated during the biorefinery of sunflower whole plant in a twin-screw extruder as the crop residue (Evon et al., 2015). In that study, starch, gelatin, and casein were the three natural binders tested and the optimal medium-density board was made of $20 \%$ starch, giving satisfactory mechanical and heat insulation properties, i.e., a flexural strength of $347 \mathrm{kPa}$ and a thermal conductivity of $78 \mathrm{~mW} /(\mathrm{m} . \mathrm{K})$, at the same time. These performances matched those of other insulating bio-based materials already available on the market perfectly. Such boards could thus contribute to the thermal insulation of buildings when positioned in walls and ceilings.

The objective of the present study was to manufacture innovative fiberboards for the thermal insulation of buildings, with improved thermal and mechanical properties. In this aim, a two-step procedure of compression molding at ambient temperature and then drying was applied. The mixture used was composed of an aqueous solution having starch as the external binder and coriander straw as the crop residue. The second objective was to study the influence of the operating conditions tested (the mechanical pre-treatment of straw, the binder content, and the straw mass) on the insulation board density, bending properties, and thermal properties. Lastly, this study also investigated the possible use of the raw materials (milled or extrusion-refined straw) as loose fill in the attics of houses.

\section{Materials and Methods}

\subsection{Raw Materials}

The coriander straw used in this study was from France. It originated from the GSN maintenaire variety and was supplied by GSN Semences (France). It was first crushed, then extrusion-refined. The two successive grinders used for crushing the straw were an Electra (France) Goulu N hammer mill fitted with a $12 \mathrm{~mm}$ screen, followed by an Electra F3 fitted with a $7.5 \mathrm{~mm}$ screen. After crushing, the moisture content of the coriander straw was determined; it was $8.9 \pm 0.1 \%$.

The commercial binder used in this study was a natural one supplied by Bostik (France), under the reference code 28474 . It had an $85 \%$ starch content. It is recommended for use as a glue, especially for wallpapers.

\subsection{Analytical Methods}

The moisture, mineral, oil, and protein contents of the coriander straw were measured using the standards ISO 665:2000, ISO 749:1977, ISO 659:2009, and ISO 5983-1:2005, respectively. The ADF-NDF (ADF for Acid Detergent Fiber, and NDF for Neutral Detergent Fiber) method of Van Soest \& Wine was used to estimate the cellulose, hemicellulose, and lignin contents, the three parietal constituents in straw (Van Soest \& Wine, 1967, 1968). The mass loss of the test sample after $1 \mathrm{~h}$ in boiling water was also used to determine the amount of water-soluble components in the straw. All measurements were made twice. 


\subsection{Refining Through Twin-Screw Extrusion}

The fibers in coriander straw were refined using a Clextral (France) Evolum HT 53 co-rotating and co-penetrating twin-screw extruder. The length of the extruder barrel was 1.9 $\mathrm{m}$. It was composed of eight modules, each 4D long, D being the screw diameter $(53 \mathrm{~mm})$, except for module 1 , which had a length of $8 \mathrm{D}$. The temperature in the modules 2 to 8 was controlled.

A Coperion (Germany) K-Tron SWB-300-N gravimetric feeder was used to control the inlet flow rate of milled coriander straw before its introduction into the first module. The feed rate of straw was set at $15 \mathrm{~kg} / \mathrm{h}$. Because no outlet restriction was applied at the end of the barrel, the extrusion-refined straw produced exited the extruder barrel freely, i.e., at atmospheric pressure. A Clextral (France) DKM Super MD-PP-63 piston pump was used to inject water at the end of module 3 using two different flow rates $(15 \mathrm{~kg} / \mathrm{h}$ and $6 \mathrm{~kg} / \mathrm{h})$, corresponding to liquid/solid (L/S) ratios of 1.0 and 0.4 , respectively.

The two different extrusion-refined materials produced in this study were referenced A (1.0 $\mathrm{L} / \mathrm{S}$ ratio) and $\mathrm{B}(0.4 \mathrm{~L} / \mathrm{S}$ ratio). For the $1.0 \mathrm{~L} / \mathrm{S}$ ratio, an aqueous solution of $47.3 \mathrm{~g} / \mathrm{L}$ of borax was also used, and this led to a third extrusion-refined material named $\mathrm{A}^{*}$. The screw profile used was identical to that used in a previous study (Uitterhaegen et al., 2017). The screw rotation speed was $150 \mathrm{rpm}$ and the extrusion temperature was $110{ }^{\circ} \mathrm{C}$.

\subsection{Particle Size Distribution}

A Nachet (France) Z $45 \mathrm{P}, \times 15$ binocular magnifier was used to evaluate the morphological characteristics of fibers in the milled coriander straw. Firstly, the Archimed (France) 4.0 software was used to take five images. Then, the lengths and diameters of all particles in the images were measured using ImageJ (USA) software.

The morphology of the extrusion-refined materials was analyzed using a TechPap (France) MorFi Compact analyzer. The latter was equipped with a CCD video camera and the MorFi v9.2 software was used for the analysis of about 30,000 fibers. For each of them, the software determined a variety of parameters, in particular the mean fiber length and the mean fiber diameter. The percentage of fines (i.e., fibers shorter than $76 \mu \mathrm{m}$ ) was also evaluated on a test sample of $2.5 \mathrm{~g}$ of dry material. It was diluted in distilled water $(1000 \mathrm{~mL})$, and intense mechanical stirring was applied to break up the aggregates. The mixture was diluted $(1: 10)$ by adding distilled water up to $1000 \mathrm{~mL}$ to a $100 \mathrm{~mL}$ aliquot. This process was repeated one more time, and the final concentration then reached $25 \mathrm{mg} / \mathrm{L}$. Because the dilution of fibers in distilled water did not result in their swelling, the measurements obtained were considered as accurate. All characterizations were performed twice.

\subsection{Apparent Density and Tapped Density}

The tapped density of the bulk materials was measured using a Granuloshop (France) Densitap ETD-20 volumenometer. The bulk materials concerned were the milled straw and the extrusion-refined straw samples. Their apparent density, before compaction, was also measured. Determinations were made twice. 


\subsection{Procedure for the Manufacture of Insulation Blocks}

After compression molding, the insulation block had to reach sufficient cohesion to allow it to be handled before drying and to enable it to be cut without risk of breaking once it had dried. The minimal straw mass needed at molding to reach sufficient cohesion was determined by experiment, and it depended directly on the tapped density of the extrusion-refined materials. It was estimated at $150 \mathrm{~g}$ and $210 \mathrm{~g}$, respectively, for the extrusion-refined straws A and B. Masses representing 133\% and $166 \%$ of the minimum mass were also investigated in this study.

Binder solutions were first prepared by solubilizing the starch-based binder in distilled water. Dissolution was conducted at room temperature, for $10 \mathrm{~min}$, under stirring. The solutions were then added to the extrusion-refined straw, and the whole was mixed manually for 5 min. Three different binder contents (w/w) were tested for the mixture: 10, 15, and $20 \%$. Compression molding of the mixtures was performed in an aluminium mold, at room temperature, for $30 \mathrm{sec}$, using a hydraulic press. The fiberboards produced were $150 \mathrm{~mm} \times$ $150 \mathrm{~mm}$ squares, and their thickness was $5 \mathrm{~cm}$.

Eighteen different molding conditions were tested (Table 1). The operating parameters tested in this study were the type of extrusion-refined material, the binder content, and the mass of raw material. For each molding condition, two insulation blocks were produced. Once molded, they were dried in a France Etuves (France) XL2520 ventilated oven. The drying step was conducted at $60{ }^{\circ} \mathrm{C}$ and its objective was to eliminate the water added to dissolve the binder. Once dried, the insulation blocks were equilibrated in a climatic chamber at $60 \%$ relative humidity $(\mathrm{RH})$ and $25{ }^{\circ} \mathrm{C}$. The equilibration lasted three weeks, after which the insulation blocks were analyzed. The mechanical properties for bending were measured using a first fiberboard. The heat insulation properties were obtained from the second block.

The milled straw was also used to produce one thermal insulation material, which was obtained from a mixture composed of milled straw (250 g), starch-based binder ( $44.1 \mathrm{~g}$, i.e., $15 \%$ in proportion to the sum of the straw and binder masses), and water (500 $\mathrm{g}$ ), by applying a pressure of $87 \mathrm{kPa}$, a molding time of $30 \mathrm{sec}$, and a drying temperature of $80{ }^{\circ} \mathrm{C}$. 
Table 1. Operating conditions used for molding the insulation blocks

\begin{tabular}{ccccccc}
\hline $\begin{array}{c}\text { Insulation } \\
\text { block }\end{array}$ & Raw material & $\begin{array}{c}\text { Binder } \\
\text { content }(\%)\end{array}$ & $\begin{array}{c}\text { Raw material } \\
\text { mass }\end{array}$ & $\begin{array}{c}\text { Raw material } \\
(\mathrm{g})\end{array}$ & Binder $(\mathrm{g})$ & $\begin{array}{c}\text { Binder } \\
\text { solution }(\mathrm{g})\end{array}$ \\
\hline AX1 & A & 10 & Minimal & 150 & 15.0 & 200.0 \\
AX2 & A & 10 & $+33 \%$ & 200 & 20.0 & 266.7 \\
AX3 & A & 10 & $+66 \%$ & 250 & 25.0 & 333.3 \\
AY1 & A & 15 & Minimal & 150 & 22.5 & 200.0 \\
AY2 & A & 15 & $+33 \%$ & 200 & 30.0 & 266.7 \\
AY3 & A & 15 & $+66 \%$ & 250 & 37.5 & 333.3 \\
AZ1 & A & 20 & Minimal & 150 & 30.0 & 200.0 \\
AZ2 & A & 20 & $+33 \%$ & 200 & 40.0 & 266.7 \\
AZ3 & A & 20 & $+66 \%$ & 250 & 50.0 & 333.3 \\
BX1 & B & 10 & Minimal & 210 & 21.0 & 280.0 \\
BX2 & B & 10 & $+33 \%$ & 280 & 28.0 & 373.3 \\
BX3 & B & 10 & $+66 \%$ & 350 & 35.0 & 466.7 \\
BY1 & B & 15 & Minimal & 210 & 31.5 & 280.0 \\
BY2 & B & 15 & $+33 \%$ & 280 & 42.0 & 373.3 \\
BY3 & B & 15 & $+66 \%$ & 350 & 52.5 & 466.7 \\
BZ1 & B & 20 & Minimal & 210 & 42.0 & 280.0 \\
BZ2 & B & 20 & $+33 \%$ & 280 & 56.0 & 373.3 \\
BZ3 & B & 20 & $+66 \%$ & 350 & 70.0 & 466.7 \\
\hline
\end{tabular}

\subsection{Flexural Properties}

The flexural properties of the test specimens were determined according to the ISO 16978:2003 standard. An Instron (USA) 33R4204 universal testing machine was used, equipped with a $500 \mathrm{~N}$ load cell. The two properties measured were the flexural strength at rupture $\left(\sigma_{f}\right)$, and the elastic modulus $\left(E_{f}\right)$. After equilibration of the insulation blocks, they were cut using a vertical bandsaw and four test specimens, each $30 \mathrm{~mm}$ wide, were obtained. An electronic digital sliding caliper having a resolution of $0.01 \mathrm{~mm}$ was used to measure their thickness and their length. The thickness and length measurements were taken at three points and two points, respectively. The mean values for thickness, t, and length, 1 , were recorded. They allowed the specimen volume to be calculated. In parallel, all the test specimens were also weighed, enabling the mean apparent density of the insulation blocks (d) to be determined. During the bending tests, a speed of $2 \mathrm{~mm} / \mathrm{min}$ was used, and the grip separation was $80 \mathrm{~mm}$. All determinations were repeated four times.

\subsection{Heat Insulation Properties}

The thermal conductivity was measured from the bulk materials and from the insulation blocks at $25{ }^{\circ} \mathrm{C}$, by using a (France) Neotim FP2C thermal conductivimeter with a hot wire. The measurements thus had an accuracy of 5\%. As a transient technique, an increase of the temperature of the tested material was measured during the hot wire test. Heat is generated thanks to a linear wire under the influence of an electric current. The length of the wire is taken to be infinite, and its diameter is considered as negligible. The wire and the associated 
thermocouple were included in a Kapton probe. They were positioned between two samples of the material under test. Then, considering the material to be semi-infinite, the heat conduction equation was solved in cylindrical coordinates, and the thermal conductivity $(\lambda)$ was thus determined. Considering a thickness of $5 \mathrm{~cm}$ for the bulk material or for the insulation block, the corresponding thermal resistance $(\mathrm{R})$ was also determined. Before the test, the equilibration of all samples was achieved in a climatic chamber, using $60 \% \mathrm{RH}$ and $25^{\circ} \mathrm{C}$ for three weeks. All determinations were carried out in triplicate.

\section{Results and Discussion}

\subsection{Characterization of Coriander Straw}

The coriander straw used in this study was chosen as the main raw material. It was made of the vegetative stalk parts of the coriander plant. Defined as the crop residue once the fruits had been harvested, it had the form of a lignocellulosic material. The chemical composition of the straw batch used in this study was determined. The main chemicals identified (percentages expressed in proportion to the dry mass of straw) were cellulose $(52.5 \pm 0.1 \%)$, hemicelluloses $(21.2 \pm 0.5 \%)$, and lignins $(9.8 \pm 0.2 \%)$.

In general, cellulose and lignin contents are $30-45 \%$ and $10-25 \%$, respectively, in most non-woody, lignocellulosic materials (Uitterhaegen et al., 2017). Here, the coriander straw used revealed a chemical composition quite comparable to those of jute fiber and wheat straw. In particular, its cellulose content was remarkably high. Because cellulose offers mechanical reinforcement for fiberboards (Uitterhaegen et al., 2017) together with a natural capacity for heat insulation (Saiah et al., 2010), it is reasonable to assume that coriander straw could be an innovative raw material for producing insulation blocks with good cohesion.

Hot-water extractives, minerals, proteins, and lipids were the additional chemical compounds identified in the coriander straw, making up $10.4 \pm 0.1 \%, 4.2 \pm 0.2 \%, 3.7 \pm 0.1 \%$, and $0.8 \pm 0.1 \%$, respectively.

\subsection{Mechanical Pre-Treatments on Coriander Straw}

The insulation blocks were produced from the coriander straw, once it had received two different mechanical pre-treatments. Firstly, it was crushed using a hammer mill, which was fitted with a $7.5 \mathrm{~mm}$ sieve during the crushing procedure. The second pre-treatment was the extrusion-refining of coriander straw using the twin-screw extrusion technology. In that case, water (L/S ratios of 1.0 and 0.4 ) or an aqueous solution of borax (L/S ratio 1.0) was added during the thermo-mechano-chemical treatment applied to the raw material. Because these two pre-treatments (grinding process and twin-screw extrusion) were markedly different, some important differences appeared for the resulting straw in terms of morphological characteristics (Table 2), and in terms of fiber densities (Table 3). A considerable improvement of the coriander fiber morphology was clearly observed in the case of the extrusion pre-treatment, and this was illustrated by a much stronger fiber aspect ratio, (17.6-26.5 instead of 4.5 for the crushing process). In fact, the fibrillation and the destructurization of fibers were largely improved by the twin-screw extrusion pre-treatment. This resulted in a more expanded, fluffy appearance of the extrusion-refined straw, 
simultaneously with the generation of fines (41-62\%). Thus, the fiber material from the extrusion treatment was logically less dense, with an apparent density varying from $45 \mathrm{~kg} / \mathrm{m}^{3}$ to $82 \mathrm{~kg} / \mathrm{m}^{3}$ instead of $95 \mathrm{~kg} / \mathrm{m}^{3}$ for the milled straw, and a tapped density between $61 \mathrm{~kg} / \mathrm{m}^{3}$ and $110 \mathrm{~kg} / \mathrm{m}^{3}$ instead of $115 \mathrm{~kg} / \mathrm{m}^{3}$ for the milled straw.

Table 2. Particle size distribution of the extrusion-refined materials, and of the milled coriander straw

\begin{tabular}{ccccc}
\hline Material & $\begin{array}{c}\text { Fiber length } \\
(\mu \mathrm{m})\end{array}$ & $\begin{array}{c}\text { Fiber diameter } \\
(\mu \mathrm{m})\end{array}$ & Aspect ratio & Fines $(\%)$ \\
\hline A & $547 \pm 21$ & $20.6 \pm 0.3$ & $26.5 \pm 1.0$ & $56.3 \pm 3.3$ \\
A* & $381 \pm 9$ & $21.7 \pm 0.0$ & $17.6 \pm 0.5$ & $62.3 \pm 16.0$ \\
B & $485 \pm 3$ & $21.2 \pm 0.1$ & $22.9 \pm 0.2$ & $40.8 \pm 0.2$ \\
Milled straw & $3541 \pm 1357$ & $838 \pm 335$ & $4.5 \pm 1.7$ & Negligible \\
\hline
\end{tabular}

Table 3. Apparent density and tapped density, and thermal properties of the bulk materials

\begin{tabular}{ccccc}
\hline Material & $\begin{array}{c}\text { Apparent } \\
\text { density }\left(\mathrm{kg} / \mathrm{m}^{3}\right)\end{array}$ & $\begin{array}{c}\text { Tapped density } \\
\left(\mathrm{kg} / \mathrm{m}^{3}\right)\end{array}$ & $\lambda(\mathrm{mW} /(\mathrm{m} . \mathrm{K}))$ & $\mathrm{R}\left(\left(\mathrm{m}^{2} . \mathrm{K}\right) / \mathrm{W}\right)$ \\
\hline A & $44.8 \pm 0.5$ & $60.6 \pm 0.3$ & $47.3 \pm 2.3$ & $1.058 \pm 0.050$ \\
A* & $59.4 \pm 0.3$ & $79.8 \pm 0.2$ & $49.3 \pm 1.5$ & $1.014 \pm 0.031$ \\
B & $81.8 \pm 1.2$ & $109.9 \pm 1.6$ & $52.5 \pm 4.9$ & $0.957 \pm 0.090$ \\
Milled straw & $95.3 \pm 4.2$ & $115.1 \pm 2.7$ & $51.0 \pm 3.0$ & $0.982 \pm 0.057$ \\
\hline
\end{tabular}

A variation in the $\mathrm{L} / \mathrm{S}$ ratio applied during the extrusion process represented different treatment severities (Theng et al., 2017). A slightly decreased fiber aspect ratio (from 26.5 to 22.9) was observed as the L/S ratio was reduced from 1.0 (A extrusion-refined material) to 0.4 (B extrusion-refined material) (Table 2). In parallel, the apparent density increased strongly, from $45 \mathrm{~kg} / \mathrm{m}^{3}$ to $82 \mathrm{~kg} / \mathrm{m}^{3}$ (Table 3). In fact, because the treatment severity increased with a lower $\mathrm{L} / \mathrm{S}$ ratio, this resulted in a reduction in fiber length (from $547 \mu \mathrm{m}$ to $485 \mu \mathrm{m})$, and thus in an increased density of the B extrusion-refined material.

At an L/S ratio of 1.0, when an aqueous solution of borax ( $\mathrm{A}^{*}$ extrusion-refined material) was used instead of water (A extrusion-refined material), the same tendency was also observed. The aspect ratio and the apparent density were then 17.6 and $59 \mathrm{~kg} / \mathrm{m}^{3}$, respectively. However, the use of borax during the twin-screw extrusion refining treatment should fire-proof the straw for future thermal insulation applications. 


\subsection{Heat Insulation Properties of Bulk Materials}

Table 3 shows the thermal properties of the bulk materials. Their thermal conductivity varied from $47.3 \mathrm{~mW} /(\mathrm{m} . \mathrm{K})$ to $52.5 \mathrm{~mW} /(\mathrm{m} . \mathrm{K})$, and this was associated with a thermal resistance varying from $1.06\left(\mathrm{~m}^{2} . \mathrm{K}\right) / \mathrm{W}$ to $0.96\left(\mathrm{~m}^{2} . \mathrm{K}\right) / \mathrm{W}$ in the case of a thickness of $5 \mathrm{~cm}$ for the bulk material. With regard to such a thermal resistance value, the bulk materials appeared as promising and viable products for insulating buildings, especially when placed in the attics of houses as loose fill. Unsurprisingly, the best thermal properties $(47.3 \mathrm{~mW} /(\mathrm{m} . \mathrm{K})$ for the thermal conductivity value) were obtained from the A extrusion-refined straw, which was the least dense bulk material tested in this study.

During the refining of coriander straw through twin-screw extrusion, when an aqueous solution of borax $\left(\mathrm{A}^{*}\right)$ was used instead of water alone (A), a very slight increase was observed for the thermal conductivity $(49.3 \mathrm{~mW} /(\mathrm{m} . \mathrm{K}))$, and this contributed to a slight deterioration in the insulating ability of the $\mathrm{A}^{*}$ extrusion-refined straw. However, to anticipate future commercial applications, the addition of borax during the twin-screw extrusion pre-treatment was undoubtedly equivalent to the application of a fire treatment for the $A^{*}$ extrusion-refined straw. In consequence, the twin-screw extrusion pre-treatment had two goals: the refining of coriander straw to reveal its fluffy appearance and thus its insulation ability and, at the same time, its fire-proofing.

\subsection{Bending and Heat Insulation Properties of Insulation Blocks}

Table 1 mentions the different molding conditions (eighteen in total) that were used to manufacture the insulation blocks. Compression molding was the molding technique used to produce them, and the influence of three different molding conditions was studied. These were the type of extrusion-refined material (A or B), the starch-based binder content (from $10 \%$ to $20 \%$ ), and the mass of the raw material (minimal, $+33 \%$ or $+66 \%$ ). All blocks were molded at room temperature. Their thickness was $5 \mathrm{~cm}$ immediately after compression molding.

The dissolution of the binder in distilled water was always possible. In parallel, for the eighteen molding conditions tested, the mixing of the binder solution with the extrusion-refined material to be tested was successfully performed manually. Once molded, the insulation blocks had to be removed from the aluminium mold with care. Next, they were dried in a ventilated oven. Conducted at a $60{ }^{\circ} \mathrm{C}$ temperature, this drying extra-step consisted in eliminating the amount of water that had been added to allow efficient dissolution of the starch-based binder. The duration for drying depended on the molding condition used, and it was between $38 \mathrm{~h}$ and $72 \mathrm{~h}$.

All the insulation blocks produced were cohesive materials. They were a mixture of lignocellulosic fibers acting as mechanical reinforcement (i.e., the extrusion-refined straw), and the starchy binder, which ensured the cohesion of the material. After the compression molding and the drying of the insulation blocks, the latter were immediately placed in a climatic chamber for equilibration. Their mechanical and thermal properties were thus assessed on materials that were already equilibrated. The moisture content of the equilibrated 


\section{Macrothink}

blocks was measured; it was between $8 \%$ and $10 \%$.

The molding conditions used largely influenced the density of the equilibrated insulation blocks. Their density varied from $127 \mathrm{~kg} / \mathrm{m}^{3}$ to $292 \mathrm{~kg} / \mathrm{m}^{3}$. Because the solid particles from the B extrusion-refined straw were smaller, this raw material generated boards with higher density. In parallel, when more binder was used or when the total raw material mass was increased, the board became denser.

Looking at the flexural properties of the insulation blocks, it is also clear that they were influenced by the molding conditions. In addition, a correlation existed between i) the flexural strength at rupture and the elastic modulus, and ii) the insulation block density (Figure 1 and Figure 2), as the higher the density of the insulation block was, the more pronounced were its bending properties. The formulation types also had an effect on the mechanical properties. As an example, when the density of the insulation block was under $200 \mathrm{~kg} / \mathrm{m}^{3}$, the formulations made from the extrusion-refined material having the longer fibers (A extrusion-refined straw) and from a low (10\%) binder content (AX formulations) revealed the highest values for both the flexural strength at rupture and the elastic modulus. In contrast, the lowest curves of the flexural properties versus density were obtained for the BZ formulations, which originated from the extrusion-refined material having the shorter fibers (B extrusion-refined straw) and from a high (20\%) binder content.

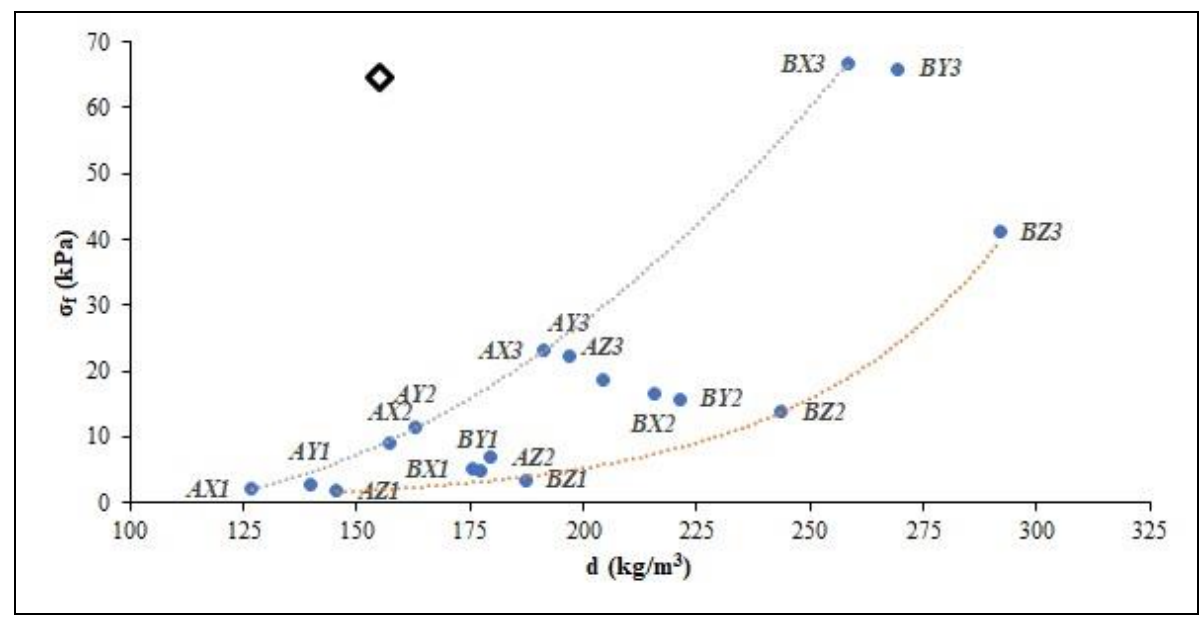

Figure 1. Flexural strength at rupture $\left(\sigma_{f}\right)$ of the insulation blocks, represented as a function of their density (open diamond for the insulation block made from the milled straw) 


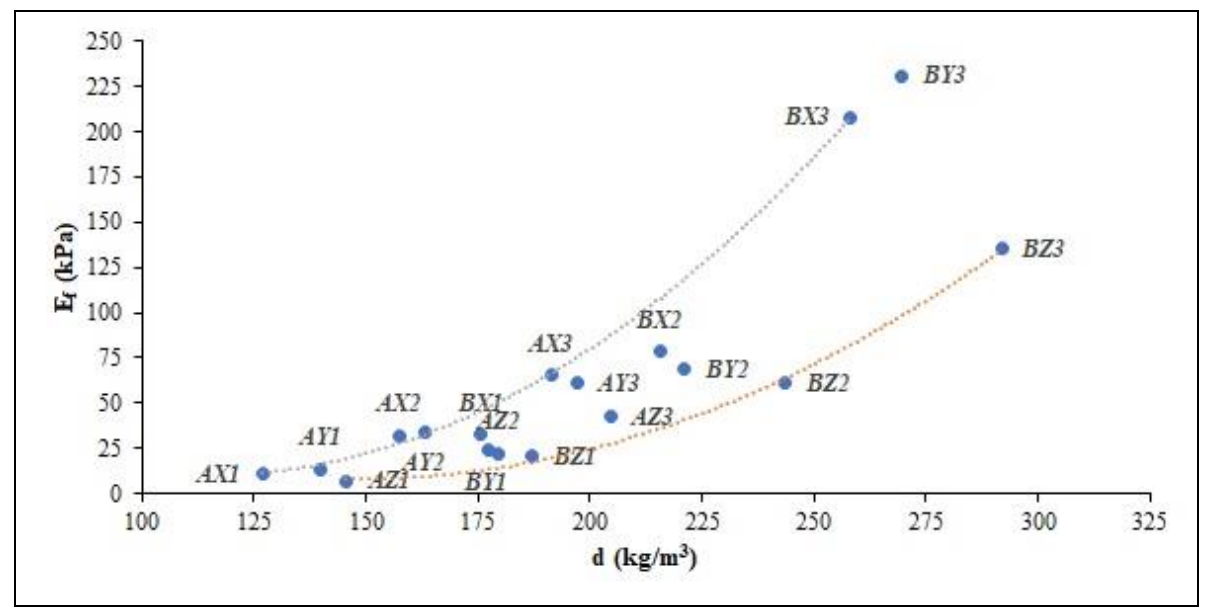

Figure 2. Elastic modulus $\left(\mathrm{E}_{\mathrm{f}}\right)$ of the insulation blocks, represented as a function of their density

In the same way, the molding conditions also influenced the thermal conductivity of the insulation blocks and the higher the density of the insulation block, the higher its thermal conductivity (Figure 3). Logically, the thermal resistance was reduced at the same time (Table 4).

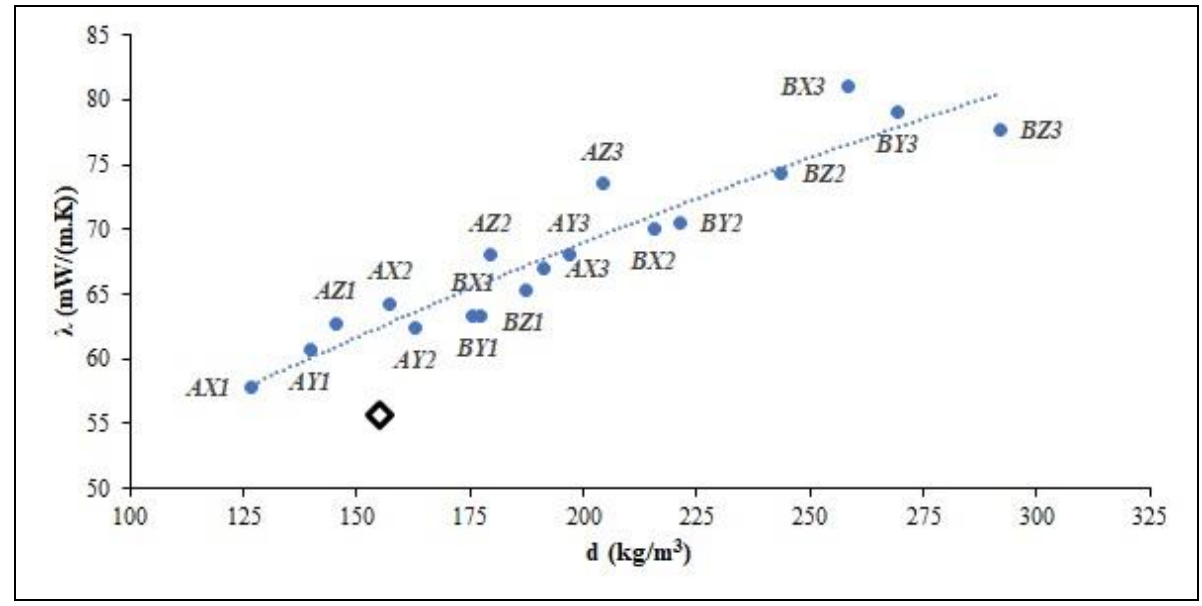

Figure 3. Thermal conductivity $(\lambda)$ of the insulation blocks at $25^{\circ} \mathrm{C}$, represented as a function of their density (open diamond for the insulation block made from the milled straw) 
Table 4. Density, thermal properties, and flexural properties of the insulation blocks

\begin{tabular}{cccccc}
\hline $\begin{array}{c}\text { Insulation } \\
\text { block }\end{array}$ & $\mathrm{d}\left(\mathrm{kg} / \mathrm{m}^{3}\right)$ & $\lambda(\mathrm{mW} /(\mathrm{m} . \mathrm{K}))$ & $\mathrm{R}\left(\left(\mathrm{m}^{2} . \mathrm{K}\right) / \mathrm{W}\right)$ & $\sigma_{\mathrm{f}}(\mathrm{kPa})$ & $\mathrm{E}_{\mathrm{f}}(\mathrm{kPa})$ \\
\hline AX1 & $126.9 \pm 1.0$ & $57.8 \pm 2.2$ & $0.866 \pm 0.034$ & $2.1 \pm 0.5$ & $11.2 \pm 1.8$ \\
AX2 & $157.3 \pm 1.5$ & $64.3 \pm 1.0$ & $0.778 \pm 0.012$ & $9.0 \pm 2.5$ & $31.9 \pm 5.2$ \\
AX3 & $191.3 \pm 2.3$ & $67.0 \pm 1.8$ & $0.746 \pm 0.020$ & $23.1 \pm 3.8$ & $65.1 \pm 8.2$ \\
AY1 & $139.7 \pm 0.9$ & $60.8 \pm 1.0$ & $0.823 \pm 0.013$ & $2.8 \pm 0.2$ & $13.7 \pm 0.6$ \\
AY2 & $163.0 \pm 0.4$ & $62.3 \pm 1.3$ & $0.802 \pm 0.017$ & $11.4 \pm 2.3$ & $34.4 \pm 2.6$ \\
AY3 & $197.0 \pm 1.2$ & $68.0 \pm 1.4$ & $0.735 \pm 0.015$ & $22.2 \pm 0.9$ & $61.1 \pm 3.3$ \\
AZ1 & $145.5 \pm 2.8$ & $62.8 \pm 0.5$ & $0.797 \pm 0.006$ & $1.7 \pm 0.3$ & $7.0 \pm 0.7$ \\
AZ2 & $179.6 \pm 2.7$ & $68.0 \pm 2.3$ & $0.735 \pm 0.025$ & $6.9 \pm 0.8$ & $22.2 \pm 3.1$ \\
AZ3 & $204.5 \pm 1.2$ & $73.5 \pm 1.9$ & $0.680 \pm 0.018$ & $18.7 \pm 1.2$ & $42.7 \pm 1.9$ \\
BX1 & $175.5 \pm 1.2$ & $63.3 \pm 1.4$ & $0.789 \pm 0.017$ & $5.1 \pm 0.3$ & $32.6 \pm 4.7$ \\
BX2 & $215.5 \pm 4.5$ & $70.0 \pm 1.7$ & $0.714 \pm 0.017$ & $16.7 \pm 1.0$ & $78.4 \pm 3.0$ \\
BX3 & $258.2 \pm 2.5$ & $81.0 \pm 2.2$ & $0.617 \pm 0.017$ & $66.6 \pm 7.2$ & $208.1 \pm 27.9$ \\
BY1 & $177.1 \pm 4.5$ & $63.3 \pm 2.6$ & $0.791 \pm 0.032$ & $4.8 \pm 0.2$ & $24.3 \pm 1.4$ \\
BY2 & $221.2 \pm 1.7$ & $70.5 \pm 1.0$ & $0.709 \pm 0.010$ & $15.8 \pm 0.3$ & $68.8 \pm 2.4$ \\
BY3 & $269.4 \pm 6.3$ & $79.0 \pm 4.7$ & $0.633 \pm 0.038$ & $66.0 \pm 1.6$ & $230.7 \pm 8.0$ \\
BZ1 & $187.2 \pm 3.7$ & $65.3 \pm 1.5$ & $0.766 \pm 0.018$ & $3.4 \pm 0.5$ & $20.3 \pm 1.9$ \\
BZ2 & $243.6 \pm 0.7$ & $74.3 \pm 1.2$ & $0.673 \pm 0.011$ & $13.9 \pm 1.8$ & $61.3 \pm 6.4$ \\
BZ3 & $291.8 \pm 1.6$ & $77.7 \pm 0.6$ & $0.644 \pm 0.005$ & $41.2 \pm 4.6$ & $135.2 \pm 7.9$ \\
\hline
\end{tabular}

To conclude, when the insulation blocks were manufactured from the extrusion-refined material with the longer fibers (i.e., the A extrusion-refined straw) and from a median starch-based binder content (i.e., 15\%), they had promising properties, both for heat insulation and bending. With a density of $163 \mathrm{~kg} / \mathrm{m}^{3}$, the AY2 material presented a good compromise between thermal and flexural properties, with a thermal conductivity of 62.3 $\mathrm{mW} /(\mathrm{m} . \mathrm{K})$ (corresponding to a thermal resistance of $0.80\left(\mathrm{~m}^{2} . \mathrm{K}\right) / \mathrm{W}$ for a thickness of $5 \mathrm{~cm}$ ), a flexural strength at rupture of $11.4 \mathrm{kPa}$, and an elastic modulus of $34.4 \mathrm{kPa}$. In addition, the cohesion of this optimal insulation block was sufficient for both handling and cutting.

Lastly, an insulation block was also successfully produced using the milled straw (Figure 4). It was molded through compression molding using an applied pressure of $87 \mathrm{kPa}$. The mixture used in that case was made of the milled straw $(250 \mathrm{~g})$ and the starch-based binder, which added a mass of $44.1 \mathrm{~g}$ (15\% of the total mass of straw plus binder, or $17.6 \%$ in proportion to the straw mass). This nineteenth and final insulation block had a thickness of $3.5 \mathrm{~cm}$, a little thinner than the other blocks in this study, which were all manufactured using the extrusion-refined straws (thickness $5 \mathrm{~cm}$ ). With a density of $155 \mathrm{~kg} / \mathrm{m}^{3}$, its thermal conductivity was $55.6 \mathrm{~mW} /(\mathrm{m} . \mathrm{K}$ ) (Figure 3), which would have corresponded to a thermal resistance of $0.90\left(\mathrm{~m}^{2} . \mathrm{K}\right) / \mathrm{W}$ if its thickness had been $5 \mathrm{~cm}$. This block made from the milled straw thus had a slightly better heat insulation ability than the AY2 one originating from the A 
extrusion-refined material. At the same time, its flexural properties were much higher, with a flexural strength at rupture of $64.5 \pm 2.9 \mathrm{kPa}$ (Figure 1) and an elastic modulus of 2.1 $\pm 0.4 \mathrm{MPa}$. In fact, the fiber bundles were much bigger inside the milled straw than inside the extrusion-refined materials, and the surface area per unit weight of crushed material was thus largely reduced. Consequently, it was reasonable to assume that the binder amount added in that case (17.6\% in proportion to the straw mass) was sufficient to completely wet the fibers, and this contributed to a final cohesion that was much improved. Looking at its usage properties, this optimal block made from the milled straw is of real interest, and it could be used for thermal insulating in buildings. For example, it could serve as filling for walls, or it could be positioned in interior partitions, as for the AY2 material.

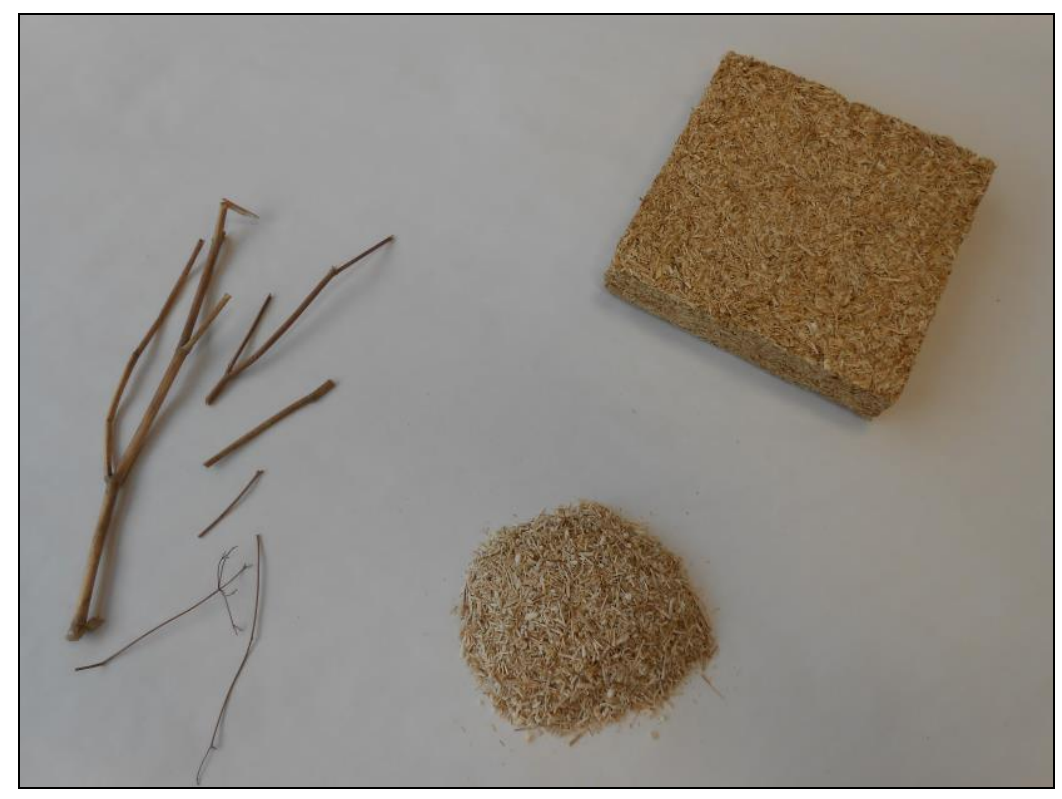

Figure 4. Photograph of the coriander straw used as raw material, of the $7.5 \mathrm{~mm}$ milled straw and of the insulation block made from it (from left to right)

For future work, to ensure the preservation of their usage properties over time, some complementary developments will be necessary for these building insulation materials. In particular, their resistance to fire, rodents, pests, and fungi should be improved, together with their resistance to water. A very recent work (Verdier et al., 2019) revealed some really promising antimicrobial capacities of glycerol esters, which are by-products from agroindustry (e.g., derivatives from the production of biodiesel). In that study, the glycerol esters used were based on undecylenic acid. And, their ability to prevent microbial growth was confirmed for two different types of thermal insulating materials, both originating from sunflower stalk. The first material tested was a light (density $50 \mathrm{~kg} / \mathrm{m}^{3}$ ) material containing pith particles. The second one was denser (density of $250 \mathrm{~kg} / \mathrm{m}^{3}$ ), and it was manufactured from bark (i.e., the depithed stalk) particles, which were previously extrusion-refined. For the two bio-based materials tested, the inhibitory effect of glycerol esters was evidenced on Aspergillus niger and also on Trichoderma viride, two microorganisms frequently identified on indoor building materials. Furthermore, the addition of glycerol esters on the surface of those two materials also revealed a reduction effect on their water adsorption, for relative 
humidities between $20 \%$ and $80 \%$. In the near future, such glycerol esters could thus be coated on the surface of the insulating materials from coriander straw developed in this study, with the double hope of protecting them from microbial growth and also of limiting their water sensitivity.

\section{Conclusion}

In this study, coriander straw was used to manufacture new thermal insulation blocks, which were all cohesive. They were made from straw and a starch binder. The cohesion of boards was obtained thanks to the binder addition. In parallel, thanks to the entanglement of lignocellulosic fibers, coriander straw acted as reinforcement. Three different operating conditions were tested: the mechanical pre-treatment of straw, the binder content, and the straw mass. The density of boards and their mechanical and heat insulation properties were influenced by those three conditions. The board density varied from $127 \mathrm{~kg} / \mathrm{m}^{3}$ to $292 \mathrm{~kg} / \mathrm{m}^{3}$. An improvement in the heat insulation properties was observed with the decrease in density. A good compromise between mechanical and heat insulation properties (thermal conductivity of $62 \mathrm{~mW} /(\mathrm{m} . \mathrm{K})$ ) was a board made of an extrusion-refined straw (type A) and $15 \%$ of the starch-based binder. The density of that specific board was $163 \mathrm{~kg} / \mathrm{m}^{3}$.

The use of a $7.5 \mathrm{~mm}$ milled straw led to even better thermal properties - with a density of 155 $\mathrm{kg} / \mathrm{m}^{3}$ and a thermal conductivity of only $56 \mathrm{~mW} /(\mathrm{m} . \mathrm{K})$. Such innovative insulation blocks could be positioned in walls and ceilings, making them appropriate for the thermal insulation of buildings in the construction industry.

The bulk materials showed an even better heat insulation capacity, especially, the type A extrusion-refined straw, which had a thermal conductivity of only $47 \mathrm{~mW} /(\mathrm{m} . \mathrm{K})$. This promising value makes this mechanically pre-treated straw a viable option for the thermal insulation of houses when used as loose fill in attic spaces.

\section{Acknowledgement}

The authors would like to thank Dr. Marc Delgado-Aguilar (LEPAMAP research group, University of Girona, Spain) who conducted the fiber morphology determinations from extrusion-refined materials.

\section{References}

Alavez-Ramirez, R., Chiñas-Castillo, F., Morales-Dominguez, V. J., \& Ortiz-Guzman, M. (2012). Thermal conductivity of coconut fibre filled ferrocement sandwich panels. $\begin{array}{lllll}\text { Construction } \quad \text { and } & \text { Building } & \text { 425-431. }\end{array}$ https://doi.org/10.1016/j.conbuildmat.2012.07.053

Ardente, F., Beccali, M., Cellura, M., \& Mistretta, M. (2008). Building energy performance: A LCA case study of kenaf-fibres insulation board. Energy and Buildings, 40, 1-10. https://doi.org/10.1016/j.enbuild.2006.12.009

Benfratello, S., Capitano, C., Peri, G., Rizzo, G., Scaccianoce, G., \& Sorrentino, G. (2013). Thermal and structural properties of a hemp-lime biocomposite. Construction and Building Materials, 48, 745-754. https://doi.org/10.1016/j.conbuildmat.2013.07.096 
Chikhi, M., Agoudjil, B., Boudenne, A., \& Gherabli, A. (2013). Experimental investigation of new biocomposite with low cost for thermal insulation. Energy and Buildings, 66, 267-273. https://doi.org/10.1016/j.enbuild.2013.07.019

Evon, P., Vandenbossche, V., Pontalier, P. Y., \& Rigal, L. (2014). New thermal insulation fiberboards from cake generated during biorefinery of sunflower whole plant in a twin-screw

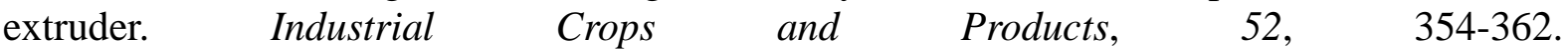
https://doi.org/10.1016/j.indcrop.2013.10.049

Evon, P., Vinet, J., Rigal, M., Labonne, L., Vandenbossche, V., \& Rigal, L. (2015). New insulation fiberboards from sunflower cake with improved thermal and mechanical properties. Journal of Agricultural Studies, 3, 194-211. https://doi.org/10.5296/jas.v3i2.7738

Khedari, J., Charoenvai, S., \& Hirunlabh, J. (2003). New insulating particleboards from durian peel and coconut coir. Building and Environment, 38, 435-441. https://doi.org/10.1016/S0360-1323(02)00030-6

Korjenic, A., Petránek, V., Zach, J., \& Hroudová, J. (2011). Development and performance evaluation of natural thermal-insulation materials composed of renewable resources. Energy and Buildings, 43, 2518-2523. https://doi.org/10.1016/j.enbuild.2011.06.012

Kymäläinen, H. R., \& Sjöberg, A. M. (2008). Flax and hemp fibres as raw materials for thermal insulations. Building and Environment, 43, 1261-1269. https://doi.org/10.1016/j.buildenv.2007.03.006

Mati-Baouche, N., De Baynast, H., Lebert, A., Sun, S., Lopez-Mingo, C. J. S., Leclaire, P., \& Michaud, P. (2014). Mechanical, thermal and acoustical characterizations of an insulating bio-based composite made from sunflower stalks particles and chitosan. Industrial Crops and Products, 58, 244-250. https://doi.org/10.1016/j.indcrop.2014.04.022

Panyakaew, S., \& Fotios, S. (2011). New thermal insulation boards made from coconut husk

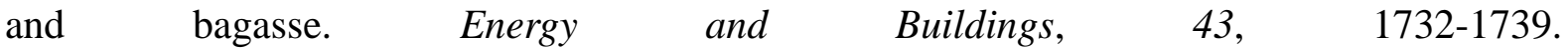
https://doi.org/10.1016/j.enbuild.2011.03.015

Sabathier, V., Ahmed Maaloum, A., Magniont, C., Evon, P., \& Labonne, L. (2017). Contribution to the design and the characterization of a fully bio-based insulating panel including sunflower pith. In: Proceedings of Congrès National de la Recherche en IUT (CNRIUT2017), Auxerre, France, 4-5 May 2017.

Saiah, R., Perrin, B., \& Rigal, L. (2010). Improvement of thermal properties of fired clays by introduction of vegetable matter. Journal of Building Physics, 34, 124-142. https://doi.org/10.1177/1744259109360059

Simon, V., Uitterhaegen, E., Robillard, A., Ballas, S., Véronèse, T., Vilarem, G., ... Evon, P. (2020). VOC and carbonyl compound emissions of a fiberboard resulting from a coriander biorefinery: comparison with two commercial wood-based building materials. Environmental Science Pollution Research, 27, 16121-16133. https://doi.org/10.1007/s11356-020-08101-y

Theng, D., Arbat, G., Delgado-Aguilar, M., Ngo, B., Labonne, L., Evon, P., \& Mutjé, P. (2017). Comparison between two different pretreatment technologies of rice straw fibers prior to fiberboard manufacturing: Twin-screw extrusion and digestion plus defibration. Industrial Crops and Products, 107, 184-197. https://doi.org/10.1016/j.indcrop.2017.05.049 
Uitterhaegen, E., Labonne, L., Merah, O., Talou, T., Ballas, S., Véronèse, T., \& Evon, P. (2017). Impact of thermomechanical fiber pre-treatment using twin-screw extrusion on the production and properties of renewable binderless coriander fiberboards. International Journal of Molecular Sciences, 18, 1-20. https://doi.org/10.3390/ijms18071539

Uitterhaegen, E., Nguyen, Q. H., Sampaio, K. A., Stevens, C. V., Merah, O., Talou, T., ... Evon, P. (2015). Extraction of coriander oil using twin-screw extrusion: feasibility study and potential press cake applications. Journal of the American Oil Chemists' Society, 82, 1219-1233. https://doi.org/10.1007/s11746-015-2678-4

Uitterhaegen, E., Parinet, J., Labonne, L., Mérian, T., Ballas, S., Véronèse, T., ... Evon, P. (2018). Performance, durability and recycling of thermoplastic biocomposites reinforced with coriander straw. Composites Part A: Applied Science and Manufacturing, 113, 254-263. https://doi.org/10.1016/j.compositesa.2018.07.038

Uitterhaegen, E., Sampaio, K. A., Delbeke, E. I. P., De Greyt, W., Cerny, M., Evon, P., ... Stevens, C. V. (2016). Characterization of French coriander oil as source of petroselinic acid. Molecules, 21, 1202. https://doi.org/10.3390/molecules21091202

Van Soest, P. J., \& Wine, R. H. (1967). Use of detergents in the analysis of fibrious feeds. IV. Determination of plant cell wall constituents. Journal of AOAC International, 50, 50-55.

Van Soest, P. J., \& Wine, R. H. (1968). Determination of lignin and cellulose in acid detergent fiber with permanganate. Journal of AOAC International, 51, 780-784.

Vandenbossche, V., Rigal, L., Saiah, R., \& Perrin, B. (2012). New agro-materials with thermal insulation properties. In: Proceedings of the 18th International Sunflower Conference. Mar del Plata, Argentina; pp. 949-954.

Verdier, T., Balthazard, L., Montibus, M., Magniont, C., Evon, P., \& Bertron, A. (2019). Development of sunflower-based insulation materials coated with glycerol esters to prevent microbial growth. Academic Journal of Civil Engineering, 37 (Special Issue ICBBM 2019), 50-56. https://doi.org/10.26168/icbbm2019.7

Zhou, X. Y., Zheng, F., Li, H. G., \& Lu, C. L. (2010). An environment-friendly thermal insulation material from cotton stalk fibers. Energy and Buildings, 42, 1070-1074. https://doi.org/10.1016/j.enbuild.2010.01.020

\section{Copyright Disclaimer}

Copyright for this article is retained by the author(s), with first publication rights granted to the journal.

This is an open-access article distributed under the terms and conditions of the Creative Commons Attribution license (http://creativecommons.org/licenses/by/4.0/). 